\title{
EFFECT OF BENZENE COMPOUNDS FROM PLANTS ON THE GROWTH AND HYPHAL MORPHOLOGY IN NEUROSPORA CRASSA
}

\author{
Fabrícia Mendonça Neves; Cristina Yoshiko Kawano; Suraia Said*
}

Departamento de Ciências Farmacêuticas, Faculdade de Ciências Farmacêuticas de Ribeirão Preto, Universidade de São Paulo, Ribeirão Preto, SP, Brasil

Submitted: May 25, 2004; Returned to authors for corrections: October 07, 2004; Approved: June 02, 2005

\begin{abstract}
The effects of the benzene compounds from plants, respectively cinnamic acid, coumaric acid, ferulic acid, caffeic acid, and cinnamic aldehyde on growth and hyphal morphology of Neurospora crassa, were investigated. Cinnamic acid, ferulic acid and cinnamic aldehyde inhibited colony growth, but produced no visible alterations on hyphae. Caffeic acid and coumaric acid did not inhibit growth, but changed hyphal morphology. The results suggest that caffeic and coumaric acids probably affect polarity maintenance (the continued deposition of wall material at the extending tip), while cinnamic aldehyde, ferulic and cinnamic acids decrease growth rate, but did not change hyphal polarity. The actin cytoskeleton and the Spitzenkörper appeared diffuse and not clearly visible when one of the benzene compounds was present in the culture.
\end{abstract}

Key words: cinnamic acid, ferulic acid, cinnamic aldehyde

\section{INTRODUCTION}

In nature, free benzene compounds are products of microbial wood degradation, but are also present in many chemical industrial wastes. Activities against microorganisms, including some phytopathogenic fungi, have been attributed to them $(27,28)$. These compounds can bind to arabinoxylans and pectins in the cell wall of plants (9). Ferulic acid esterases, enzymes that hydrolyze the ester bond linking ferulic acid to polysaccharides bound to plant cell walls, have been identified in many fungi $(7,6,31)$, which works in synergy with cell wall degrading enzymes, such as xylanases, releasing ferulic acid (2).

It is known that benzene compounds present in many vegetable essential oils, have a preservative effect (15). Most studies of these compounds have been developed in bacteria, and few in fungi $(3,5,23)$. The microbial cell growth inhibition mechanism by these compounds has not been elucidated. The objective of this study was to examine the effect of subinhibitory concentrations of some benzene compounds on germination, growth, branching and the cytoskeleton of Neurospora crassa. The Ascomycete $N$. crassa belongs to the
Sordariaceae family and is a filamentous fungus with many properties that are advantageous for studying development. This eukaryotic organism can be grown in a defined medium under controlled conditions and it is well characterized from a genetic, biochemical and more recently molecular biology stand point, becoming it an attractive model organism for many different researches (24).

\section{MATERIALS AND METHODS}

\section{Strain and growth conditions}

The wild type Neurospora crassa (74 OR 8-1a, ATCC) was used throughout this work. Fungus was maintained on slopes of Vogel's minimal medium (MM), supplemented with $2 \%$ (w/v) glucose and stored at $4^{\circ} \mathrm{C}$. For the experiments they were grown in semi-solid (SMM) or liquid (LMM) Vogel's minimal medium. Cinnamic, p-coumaric, ferulic and caffeic acids were purchased from Sigma; cinnamic aldehyde from Aldrich. The compounds were dissolved in $20.8 \%(\mathrm{w} / \mathrm{v})$ dimethylsulfoxide (DMSO) solution and added to steriled SMM or LMM at $250 \mu \mathrm{g} / \mathrm{mL}$. The final concentration of DMSO in the medium was never

*Corresponding Author. Mailing address: Departamento de Ciências Farmacêuticas, Faculdade de Ciências Farmacêuticas de Ribeirão Preto, USP. Av. Zeferino Vaz s/n, Monte Alegre. 14040- 903, Ribeirão Preto, SP, Brasil. Tel.: (+5516) 602-4224, Fax: (+5516) 633-1941. E-mail: susaid@usp.br 
higher than $0.1 \%$; appropriate controls with DMSO were prepared.

\section{Germination and colony growth analysis}

To evaluate the effects of benzene compounds on $N$. crassa germination, LMM containing or not benzene compounds, were inoculated with $1 \times 10^{5}$ conidia/mL and incubated at $30^{\circ} \mathrm{C}$ in a rotary shaker at $110 \mathrm{rpm}$. At different period of time germlings were collected, fixed for $15 \mathrm{~min}$ with $3.7 \%$ paraform-aldehyde, $10 \mathrm{mM}$ Triton X-100 and $0.01 \%$ glutaraldehyde in $60 \mathrm{mM}$ Pipes buffer (pH 6.8) with $10 \mathrm{mM} \mathrm{MgSO}_{4}$ and $10 \mathrm{mM} \mathrm{EGTA}$ (buffer A). After being rinsed at least 3 times with buffer $\mathrm{A}$, germlings were stained for $15 \mathrm{~min}$ in Calcofluor White (1 mg/mL distilled water), rinsed again with the same buffer and mounted in glycerol $1 \mathrm{mg} / \mathrm{mL} \mathrm{p-}$ phenylenediamine in PBS. Photographs were taken with a TMAX 400 film, under a fluorescence microscope (Zeiss Axioskop) using Zeiss MC 80 microscope camera system and 100x oil objective. Colony growth was evaluated by central inoculation of $1 \times 10^{6}$ conidia/mL onto SMM in Petri dishes; the colony diameters were measured with a ruler after 18 and 24 hours of incubation at $30^{\circ} \mathrm{C}$.

\section{Hyphal morphology analysis}

The analyses of hyphal morphology was performed inoculating and spreading approximately 50 conidia on sterile dialysis membrane placed on the surface of SMM supplemented or not, with a benzene compound and after incubation at $30^{\circ} \mathrm{C}$ for different time the hyphae were examined and photographed using a Zeiss binocular stereomicroscope with transmitted light. For actin cytoskeleton analysis by indirect immunofluorescence Tynsley's method (30), was adapted as follows: approximately 100 conidia were inoculated and spread on sterile strips of dialysis membranes $(1 \mathrm{~cm} \times 2 \mathrm{~cm})$ overlying SMM supplemented or not, with a benzene compound and incubated at $30^{\circ} \mathrm{C}$ for different periods of time. Hyphae were then treated for $15 \mathrm{~min}$ in the fixing solution, and rinsed at least 3 times with buffer $\mathrm{A}$. Then the cell wall was permeabilized for $10 \mathrm{~min}$ at room temperature using an enzymatic digestion solution containing 30 nM MES, $1.0 \mathrm{mg} / \mathrm{mL}$ BSA, $9.0 \mathrm{mg} / \mathrm{mL}$ Driselase, 1.0 $\mathrm{mg} / \mathrm{mL}$ Novozyme $234,1.0 \mu \mathrm{L}$ of protease inhibitors solution (1.0 mM Antipain, 1.0 mM Chymostatin, 1.0 $\mathrm{mM}$ Pepstatin) plus 1.0 mM PMSF. After several rinses with buffer A, cells were incubated for 45 min with the primary antibody (C4-monoclonal mouse anti-chicken gizzard actin $\operatorname{IgG} 1$, diluted 1:100), under humid conditions at $30^{\circ} \mathrm{C}$, in the dark. After this incubation and several rinses with solution A, the cells were reincubated, under the same conditions, with the secondary antibody (Cy3-conjugated goat antimouse $\mathrm{IgG}$ ), diluted 1:50). Both antibodies had been obtained from Cedarlane; Hornby, Ont., Canada and were diluted in buffer A, containing 1\% (v/v) BSA. Following final incubation, cells were again rinsed several times in buffer A, mounted and registered as described previously.

\section{RESULTS AND DISCUSSION}

\section{Effects of benzene compounds on germling polarization, colony growth and hyphal morphology}

Colony growth of $N$. crassa decreased less than $8 \%$ in media supplemented with caffeic or coumaric acids when compared with control culture; however, after $24 \mathrm{~h}$ in ferulic acid or cinnamic acid, growth was inhibited by respectively 20 and 94\% (22). Cinnamic aldehyde also inhibited $40 \%$ the colony growth (result not shown). In order to investigate whether these effects were due to alterations in $N$. crassa germination, conidia were inoculated with these compounds, and the initial steps of germination followed. Normally, a polarized germ tube was present in $94 \%$ of $N$. crassa germlings after a $5 \mathrm{~h}$ incubation period in $\mathrm{LMM}$ at $30^{\circ} \mathrm{C}$; however at the same conditions, but in the presence of $250 \mu \mathrm{g} / \mathrm{mL}$ cinnamic aldehyde or cinnamic acid, it was $19 \%$ and $43 \%$ respectively. No significant differences in germ tube emergence times were observed when other benzene compounds were tested. After 10 hours of incubation in the control and other cultures supplemented with benzene compounds, as ferulic acid, all conidia had germinated and long hyphae could be visualized while in those supplemented with cinnamic aldehyde it was $70 \%$ and with cinnamic acid it was $75 \%$

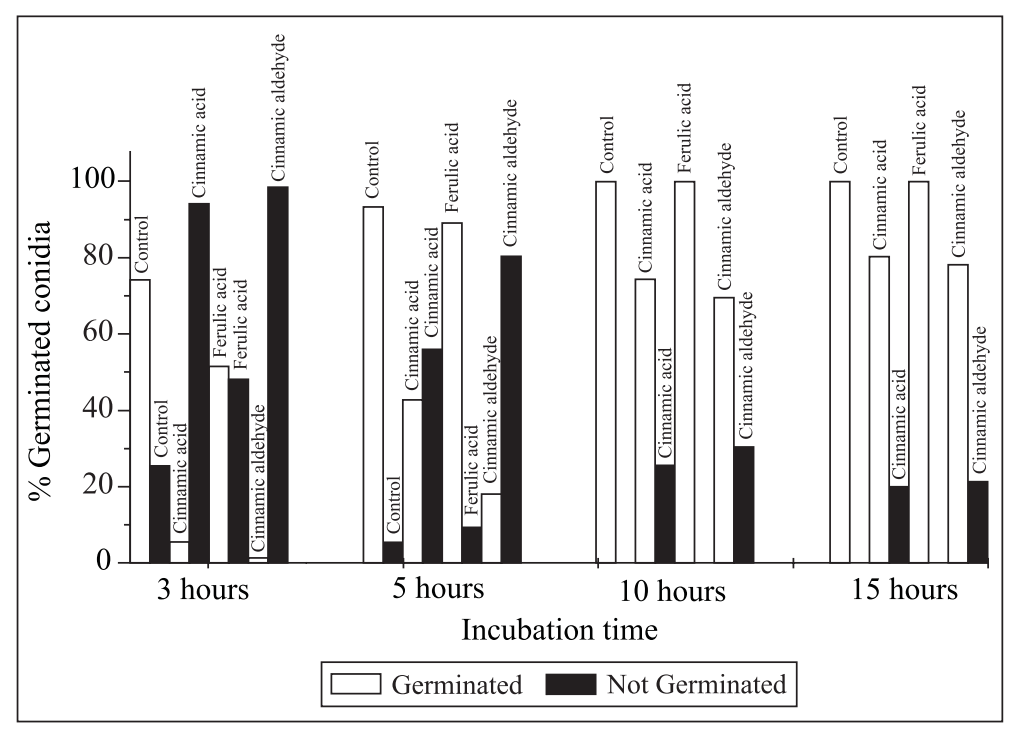

Figure 1. Effects of some benzene compounds on the Neurospora crassa germination. Conidia were incubated at $30^{\circ} \mathrm{C}$ in liquid Vogel's minimal media supplemented or not with $250 \mu \mathrm{g} / \mathrm{mL}$ benzene compounds and incubated for $3 ; 5 ; 10$ and 15 hours. Germlings were counted under light microscope. Values are the average of at least 2 replicates. 
(Fig. 1). In these two last conditions most of cells was yet germlings and interestingly about $7 \%$ presented bipolar germination (Fig. 2). These results suggest that $250 \mu \mathrm{g} / \mathrm{mL}$ of cinnamic acid or cinnamic aldehyde delayed the germination as well as disturbed the establishment of polarity (the choice of the place where the germ tube will emerge) in $7 \%$ of the cells. According to Momany et al. (17), multiple germ tubes detected on the Aspergillus nidulans mutant swoA, could be due to overproduction or diffusion of the signal for germ tube emergence. On the other hand, the sphingolipid pathway is recognized as being an important signaling system preserved from fungi to humans; metabolites derived from its breakdown are bioactive molecules, considered to be implicated as second messenger mediators of various cell functions. Sphingolipid biosynthesis in A. nidulans has been reported as being essential for the establishment of polarity, because the inactivation of inositol phosphorylceramide synthase or serine palmitoyltransferase, enzymes involved in sphingolipid biosynthesis, prevent polarized growth during spore germination (4). Here, benzene compounds could have acted either on the signal for germ tube emergence or on sphingolipid biosynthesis proper.

It is known that after germination, $N$. crassa germlings undergo polarized growth through tip extension and branching at irregular intervals (16). When media were supplemented with benzene compounds, the cells became abnormally branched (Fig. 3). In the presence of cinnamic aldehyde (Fig. 3C), ferulic acid (Fig. 3B) or cinnamic acid (Fig. 3D), hyphae were shorter than those of controls (Fig. 3A) and colony growth was damaged. Considering that benzene compounds may be toxic to cells, the slower-growing hyphae detected in treated cultures, may have resulted from biochemical disturbances caused by these compounds in one or more metabolic pathways. This subject has not been clarified yet, although these compound's antimicrobial activities against many microorganisms are known $(29,15,28)$. Growth inhibition in $N$. crassa has been reported to be consequent to kinesin, calcineurin or dynein deficiencies $(25,18,21)$, or to increased cytosol calcium levels (20). Cinnamic aldehyde, ferulic and cinnamic acids may have inhibited Neurospora crassa growth by disturbing the synthesis of a cell component involved in cytoskeleton development or in the regulation of the cell calcium gradient. Caffeic (Fig. 3E) and coumaric acid (Fig. 3F) produced splitted tips, also known as dichotomous branching; however no significant differences in colony growth were caused by these compounds. Dichotomous branching has also been detected in A. nidulans following inhibition of inositol phosphorylceramide (IPC) synthase activity, demonstrating that sphingolipids are essential for cell polarity (4).

Another aspect to be regarded in this subject, is that intracellular osmolarity in fungi is higher than in the environment. This leads to a positive turgor pressure, which has a fundamental role in determining how the cell wall expands in space (1). Glycerol appears to be responsible for adjusting
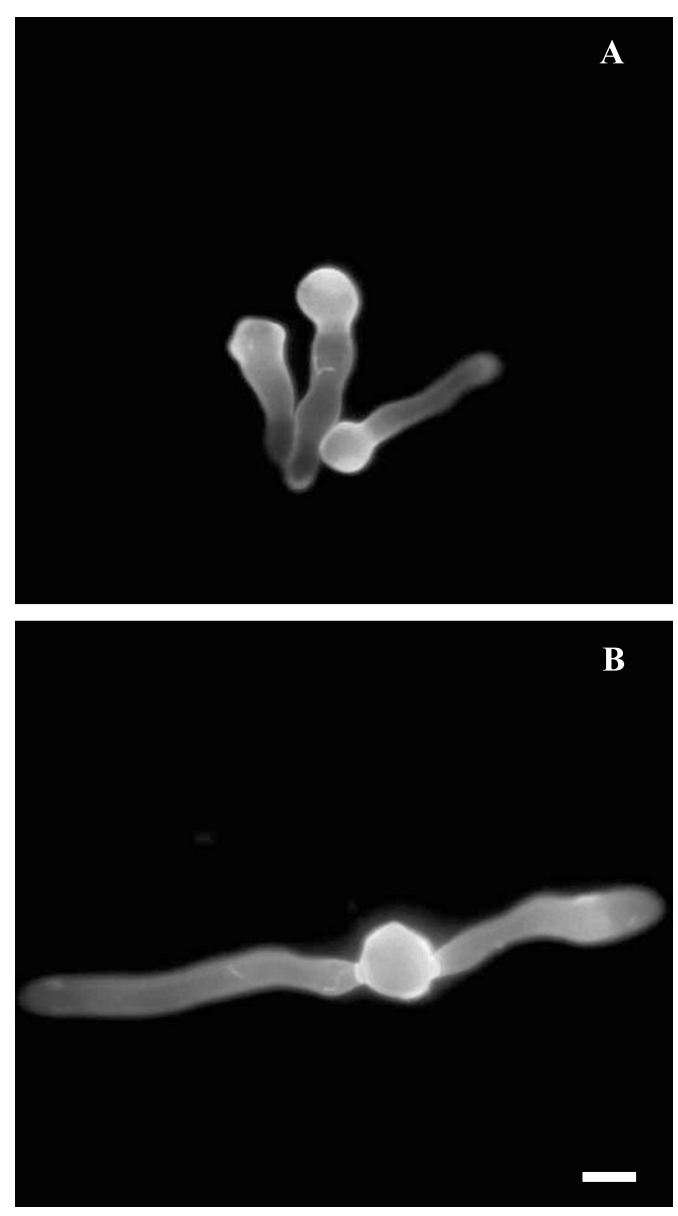

Figure 2. Effect of cinnamic acid and cinnamic aldehyde on the germ tube polarity establishment in Neurospora crassa. Conidia were incubated at $30^{\circ} \mathrm{C}$ in Vogel's minimal media for $5 \mathrm{~h}$ (A) or for $5 \mathrm{~h}$ in media supplemented with $250 \mu \mathrm{g} / \mathrm{mL}$ cinnamic acid or cinnamic aldehyde (B). Germlings were fixed and cell wall stained with Calcofluor. Bar, 5.0 $\mu \mathrm{m}$.

intracellular solute concentration (19). Abnormal hyphal morphology has been reported in a null mutant of $A$. nidulans glycerol 3-phosphate dehydrogenase that had reduced glycerol 3-phosphate levels (8). Han and Prade (11) have suggested that tip splitting observed in an A. nidulans mutant, in which the salt stress gene was deleted, is a consequence of the cell's inability to maintain turgor pressure. Thus any alteration in systems responsible for maintaining intracellular osmolarity, can lead to tip splitting.

These results suggest that caffeic and coumaric acids probably affect polarity maintenance (the continued deposition of wall material at the extending tip), while cinnamic aldehyde, ferulic and cinnamic acids decrease growth rate, but did not change hyphal polarity. 

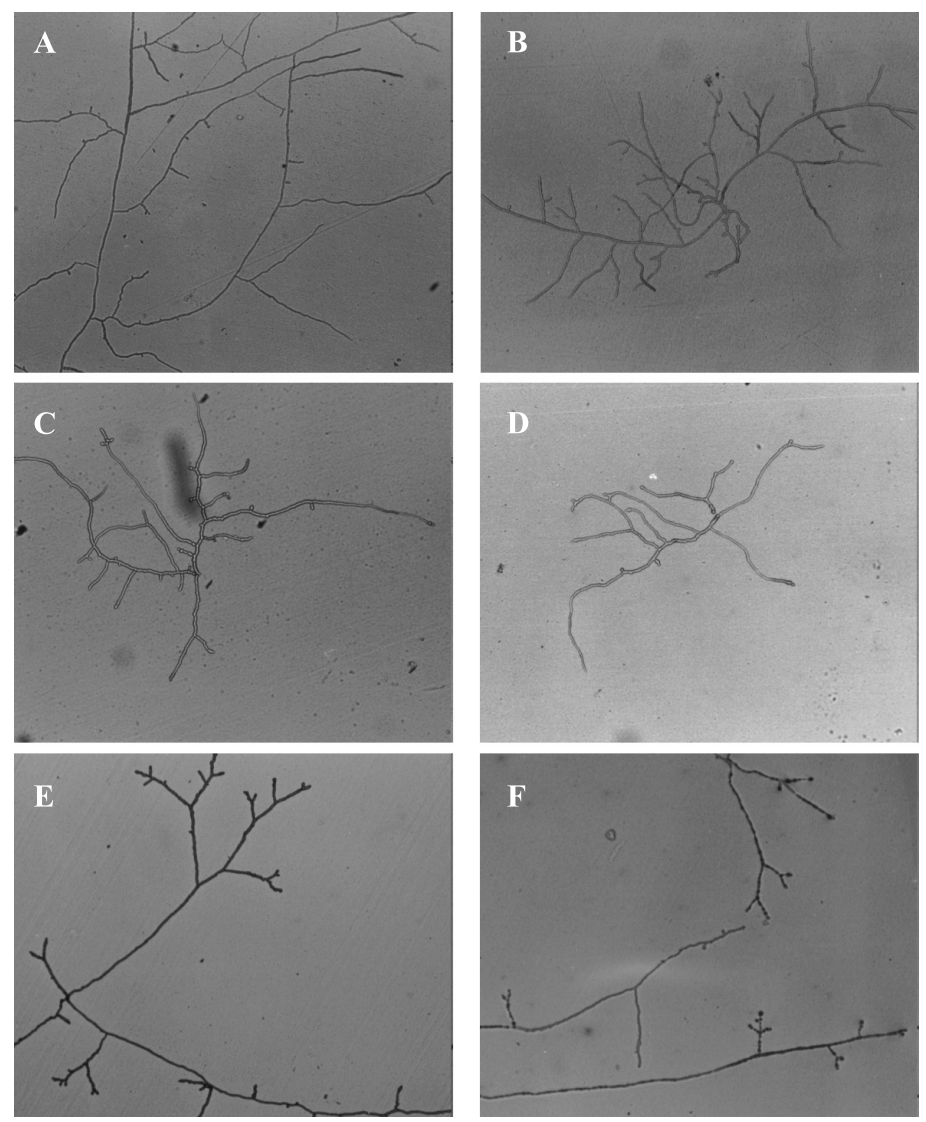

Figure 3. Alterations induced by benzene compounds on the hyphal branching and colony growth. Conidia were inoculated on dialysis membrane placed on solid Vogel's minimal media (A) or on media supplemented with $250 \mu \mathrm{g} / \mathrm{mL}$ ferulic acid (B), cinnamic aldehyde (C), cinnamic acid (D), caffeic acid (E) or coumaric acid (F). The cultures were incubated at $30^{\circ} \mathrm{C}$ for $17 \mathrm{~h}$ and photographs were taken using a stereomicroscope. Magnification, x 125.

\section{Analysis of actin distribution in treated hyphae}

It is known that in many fungi actin, as well as microtubules, are involved in cytoplasmic migration and organelle movement during hyphal elongation; alterations in these components of the cytoskeleton change growth rates and hyphal morphology $(12,13,14)$. We therefore decided to analyze whether the effects of benzene compounds on mycelium growth, and maintenance of polarity were related to actin distribution. We observed that actin immuno-staining at the tip of hyphae grown in presence of cinnamic aldehyde (Fig. 4B), ferulic acid (Fig. 4C), cinnamic acid (Fig. 4D), coumaric acid (Fig. 4E) or caffeic acid (Fig. 4F), appeared to be weaker than in the control culture; Spitzenkörper were diffuse and not as clearly visible as in untreated hyphae (Fig. 4A). Spitzenkörper is a structure characterized by many vesicles localized in the apical dome of growing hyphal tips found in higher fungi $(10,25)$. In $N$. crassa hyphae, actin is seen in Spitzenkörper and in fine peripheral plaques associated with the plasma membrane and clustered subapically (14). Evidences have suggested that kinesin, the microtubuledependent mechanochemical enzyme, plays an important role in intracellular movements associated with membrane organelles $(25,26)$. In the kinesin-deficient mutant, growth was inhibited by $24 \%$ and many alterations in cell morphogenesis were detected, including absence of Spitzenkörper (25). Cinnamic aldehyde, ferulic acid and cinnamic acid reduced colony growth and since the Spitzenkörper is correlated with hyphal extension (10), one may conclude that our results are consequences of growth inhibition. Interestingly, even in the presence of coumaric or caffeic acid, which induced dichotomous tips formation, the actin staining presented as in the other three compounds. Concluding, cinnamic aldehyde, ferulic acid
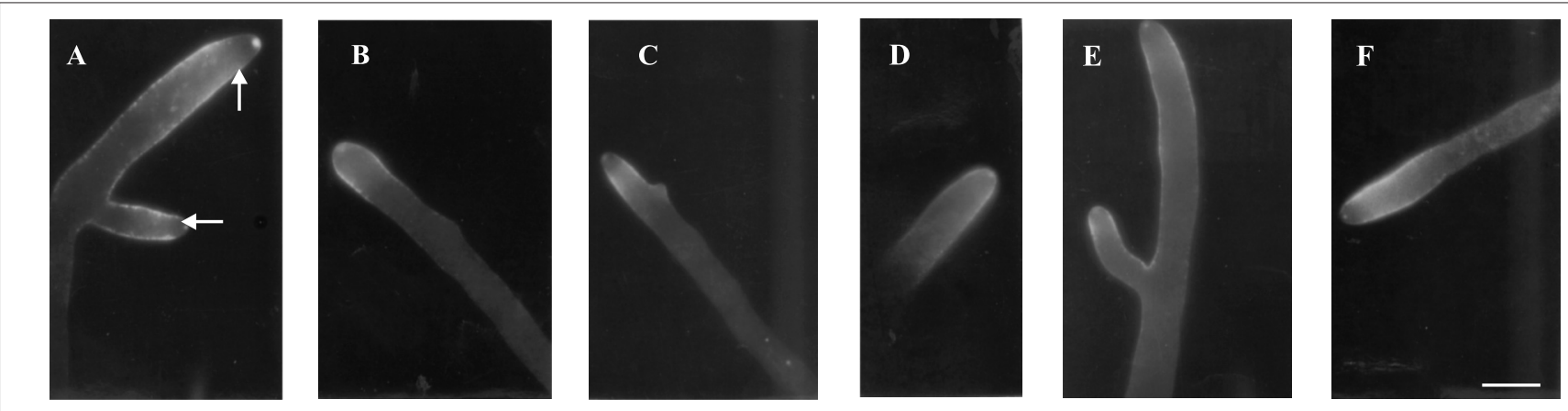

Figure 4. Distribution of actin in cultures cultivated in benzene compounds presence. Conidia were inoculated on dialysis membrane placed on solid Vogel's minimal media (A) or on media supplemented with $250 \mu \mathrm{g} / \mathrm{mL}$ cinnamic aldehyde (B), ferulic acid (C), cinnamic acid (D), coumaric acid (E) and caffeic acid (F). The cultures were incubated at $30^{\circ} \mathrm{C}$ for $24 \mathrm{~h}$. Spitzenkörper is showed by arrows in A. Bar, $5.0 \mu \mathrm{m}$. 
and cinnamic acid appear to affect cytoskeleton components or the calcium gradient, leading to a decreased growth rate, while the effects of caffeic and coumaric acid may be mainly on sphingolipids or glycerol synthesis.

In nature, more than one benzene compound are present in plants; synergistic effects are maybe a strategy of the plant to protect itself against most of the fungi by inhibiting, delaying and altering their growth rate; however, some fungi may escape from this control, probably in consequence of the presence of enzymes which degrade or transform benzene compounds as related to $N$. crassa (22).

\section{ACKNOWLEDGEMENTS}

This work was supported by grants from Fundação de Amparo a Pesquisa do Estado de São Paulo (FAPESP) no 97/ 03619-7. FMN received a master fellowship from FAPESP n ${ }^{\circ}$ 98/ 06494-3. This work is part of a thesis submitted by FMN to Faculdade de Ciências Farmacêuticas-USP de Ribeirão Preto in partial fulfillment of requirements for master's degree. We are grateful to M.A.S.C. Chellegatti for typing the manuscript.

\section{RESUMO}

\section{Efeito de compostos benzênicos de plantas sobre o crescimento e a morfologia das hifas em Neurospora crassa}

Os efeitos de compostos benzênicos de plantas, respectivamente ácido cinâmico, ácido coumárico, ácido ferúlico, ácido cafeico e aldeído cinâmico, sobre o crescimento da colônia e a morfologia das hifas de Neurospora crassa foram investigados. Ácido cinâmico, ácido ferúlico e aldeído cinâmico inibiram o crescimento colonial, mas não produziram diferenças visíveis sobre as hifas. Ácido cafeico e ácido coumárico não inibiram o crescimento, mas alteraram a morfologia das hifas. Os resultados sugerem que os ácidos cafeico e coumárico afetam provavelmente a manutenção da polaridade (a contínua deposição de material da parede na ponta em extensão), enquanto aldeído cinâmico e os ácidos cinâmicos e ferúlico diminuem a velocidade de crescimento, mas não alteram a polaridade das hifas. Actina no citoesqueleto e no Spitzenkörper apareceu difuso e não estava claramente visível na presença de um dos compostos benzênicos na cultura.

Palavras-chave: ácido cinâmico, ácido ferúlico, aldeído cinâmico

\section{REFERENCES}

1. Bartnicki-Garcia, S.; Bracker, C.E.; Gierz, G.; Lopez-Franco, R.; Lu, $\mathrm{H}$. Mapping the growth of fungal Hyphal: orthogonal cell wall expansion during tip growth and the role of turgor. Biophys. J., 79(5), 2382-2390, 2000.
2. Bartolomé, B.; Faulds, C.B.; Tuohy, M.; Hazlewood, G.P.; Gilbert, H.J.; Williamson, G. Influence of different xylanases on the activity of ferulic acid esterases on wheat bran. Biotechnol. Appl. Biochem., 22, 65-73, 1995.

3. Chamkha, M.; Garcia, J.L.; Labat, M. Metabolism of cinnamic acid by some Clostridiales and emendation of the descriptions of Clostridium aerotolerans, Clostridium celerecrescens and Clostridium xylanolyticum. Int. J. Syst. Evol. Microbiol., 51, 2105-2111, 2001.

4. Cheng, J.; Park, T.S.; Fischl, A.S.; Ye, X.S. Cell cycle progression and cell polarity require sphingolipid biosynthesis in Aspergillus nidulans. Mol. Cell. Biol., 21(18), 6198-6209, 2001.

5. Delneri, D.; Degrassi, G.; Rizzo, R.; Bruschi, C.V. Degradation of trans-ferulic and p-coumaric acid by Acinetobacter calcoaceticus DSM 586. Biochim. Biophys. ACTA, 1244(2-3), 363-367, 1995.

6. De Vries, R.P.; Michelsen, B.; Poulsen, C.H.; Kroon, P.A.; van den Heuvel, R.H.; Faulds, C.B.; Williamson, G.; van den Hombergh, J.P.; Visser, J. The faeA genes from Aspergillus niger and Aspergillus tubingensis encode ferulic acid esterases involved in degradation of complex cell wall polysaccharides. Appl. Environ. Microbiol., 63, 4638-4644, 1997.

7. Faulds, C.B.; Williamson, G. Release of ferulic acid from wheat bran by a ferulic acid esterase (FAE-III) from Aspergillus niger. Appl. Microbiol. Biotechnol., 43, 1082-1087, 1995.

8. Fillinger, S.; Ruijter, G.; Tamas, M.J.; Visser, J.; Thevelein, J.M.; d'Enfert, C. Molecular and physiological characterization of the NAD-dependent glycerol 3-phosphate dehydrogenase in the filamentous fungus Aspergillus nidulans. Mol. Microbiol., 39(1), 145-157, 2001

9. Fry, S.C. Phenolic components of the primary cell wall. Feruloylated disaccharides of D-galactose and L-arabinose from spinach polysaccharide. Biochem. J., 203, 493-504, 1982.

10. Grove, S.N.; Braker, C.E. Protoplasmic organization of hyphal tips among fungi: vesicles and Spitzenkörper. J. Bacteriol., 104, 9891009, 1970.

11. Han, K.H.; Prade, R.A. Osmotic stress-coupled maintenance of polar growth in Aspergillus nidulans. Mol. Microbiol., 43, 1065-1078, 2002.

12. Heath, I.B. The roles of actin in tip growth of fungi. Int. Rev. Cytol., 123, 95-127, 1990.

13. Heath, I.B. Integration and regulation of hyphal tip growth. Can. J. Bot., 73 (suppl) 1, S131- S139, 1995.

14. Heath, I.B.; Gupta, G.; Bai, S. Plasma membrane-adjacent actin filaments, but not microtubules, are essential for both polarization and hyphal tip morphogenesis in Saprolegnia ferax and Neurospora crassa. Fungal Genet. Biol., 30, 45-62, 2000.

15. Hoskins, J.A. The occurrence, metabolism and toxicity of cinnamic acid and related compounds. J. Appl. Toxicol., 4, 283-292, 1984.

16. McLean, K.M.; Prosser, J.I. Development of vegetative mycelium during colony growth of Neurospora crassa. Trans. Br. Mycol. Soc., 88, 489-495, 1987.

17. Momany, M.; Westfall, P.J.; Abramowsky, G. Aspergillus nidulans swo mutants show defects in polarity establishment, polarity maintenance and hyphal morphogenesis. Genetics, 151, 557-567, 1999.

18. Prokisch, H.; Yarden, O.; Dieminger, M.; Tropschug, M.; Barthelmess, I.B. Impairment of calcineurin function in Neurospora crassa reveals its essential role in hyphal growth, morphology and maintenance of the apical $\mathrm{Ca}^{+2}$ gradient. Mol. Gen. Genet., 256, 104-114, 1997.

19. Redkar, R.J.; Herzog, R.W.; Singh, N.K. Transcriptional activation of the Aspergillus nidulans gpdA promoter by osmotic signals. Appl. Environ. Microbiol., 64, 2229-2231, 1998.

20. Reissig, J.L.; Kinney, S.G. Calcium as a branching signal in Neurospora crassa. J. Bacteriol., 154, 1397-1402, 1983. 
21. Riquelme, M.; Roberson, R.W.; McDaniel, D.P.; Bartnicki-Garcia, S. The effects of ropy-1 mutation on cytoplasmic organization and intracellular motility in mature Hyphal of Neurospora crassa. Fungal Genet. Biol., 37(2), 171-179, 2002.

22. Said, S.; Neves, F.M.; Griffiths, A.J.F. Cinnamic acid inhibits the growth of the fungus Neurospora crassa, but is eliminated as acetophenone. Int. Biodeg. Biodet., 54(1), 1-6, 2004.

23. Schoeman, M.W.; Dickinson, D.J. Aureobasidium pullulans can utilize simple aromatic compound as sole source carbon in liquid culture. Lett. Appl. Microbiol., 22, 120-131, 1996.

24. Schimt, J.C.; Brody, S. Biochemcal genetics of Neurospora crassa conidial germination. Bacrteriol. Rev., 40, 1-41, 1976.

25. Seiler, S.; Nargang, F.E.; Steinberg, G.; Schliwa, M. Kinesin is essential for cell morphogenesis and polarized secretion in Neurospora crassa. EMBO J., 16, 3025-3034, 1997.

26. Steinberg, G.; Schliwa, M. The Neurospora organelle motor: a distant relative of conventional kinesin with unconventional properties Mol. Biol. Cell., 6, 1605-1618, 1995.
27. Suhr, K.I.; Nielsen, P.V. Antifungal activity of essential oils evaluated by two different application techniques against rye bread spoilage fungi. J. Appl. Microbiol., 94(4), 665-674, 2003.

28. Tawata, S.; Taira, S.; Kobamoto, N.; Zhu, J.; Ishihara, M.; Toyama S. Synthesis and antifungal activity of cinnamic acid esters. Biosci. Biotechnol. Biochem., 60, 909-910, 1996.

29. Theodorou, M.K.; Gascoyne, D.J.; Akin, D.E.; Hartley, R.D. Effect of phenolic acids and phenolics from plant cell walls on rumenlike fermentation in consecutive bath culture. Appl. Environ. Microbiol. 53, 1046-1050, 1987.

30. Tinsley, J.H.; Minke, P.F.; Bruno, K.S.; Plamann, M. p150 ${ }^{\text {Glued, the }}$ largest subunit of the dynactin complex, is nonessential in Neurospora but required for nuclear distribution. Mol. Biol. Cell., 7, 731-742, 1996.

31. Williamson, G.; Kroon, P.A.; Faulds, C.B. Hairy plant polysaccharides: a close shave with microbial esterases. Microbiology, 144, 20112023, 1998 